\title{
Reaction of tangerines genotypes to Elsinoe fawcettii under natural infection conditions
}

\author{
Marcelo Claro de Souza ${ }^{1 *}$, Eduardo Sanches Stuchi ${ }^{2}$ and Antonio de Goes ${ }^{3}$
}

Received 11 February 2010

Accepted 30 September 2010

\begin{abstract}
A citrus scab disease, caused by Elsinoe fawcettii, is currently found in all citrus areas throughout Brazil. That being, given the importance of this casual agent, the behavior of tangerines and hybrids influenced by this pathogen was evaluated under natural infection conditions. This study was performed with plants around 15 years old without irrigation; 100 fruits of three plants were collected during harvest season, using a grade scale varying from 0 (absence of symptoms) to 6 (severe symptoms) the level of disease severity was determined. Among the cultivars, citrus scab resistance was observed in Citrus deliciosa, C. tangerina, C. nobilis; a mandarin hybrid (C. nobilis $x$ C. deliciosa) and a satsuma hybrid (C. unshiu $x$ C. sinensis). Among the other genotypes, symptoms were observed with levels of severity ranging from 1 to 3 , indicating moderate resistance.
\end{abstract}

Key words: Citrus scab, citrus crop, resistant varieties.

\section{INTRODUCTION}

In many citrus production areas around the world, Elsinoe fawcettii is one of the main fungi diseases found. It attacks a wide variety of citrus species and cultivars, resulting in scab disease on leaves, twigs, and fruits (Timmer et al. 1996, Hyun et al. 2007, Goes and Reis 2009).

Depending on the species or pathotype of the scab involved, this disease may affect citric commercial species such as sweet orange (Citrus sinensis), lemon (C. limon), grapefruit ( $C$. paradisi), many tangerine and mandarin lines (C. reticulata), satsuma mandarin (C. unshiu), clementine (C. clementina), and their hybrids, as well as species used for rootstocks such as sour orange (C. aurantium), rough lemon (C. jambhiri), and cleopatra mandarin (C. reshni) (Hyun et al. 2009).
In Brazil, E. fawcettii is responsible for citrus scab. The disease is widespread in many humid, citrus-cultivating areas around the world and decreases fruit values on the fresh-fruit market (Feichtenberger et al. 1986). In young plants or under severe infection, it may cause significant fruit drop. Furthermore, roughness in the fruit peel caused by this disease reflects the difficulty to control some important citrus plagues like citrus leprosis mites (Brevipalpus phoenicis) (Rodrigues et al. 2003).

The necrotic lesions caused by E. fawcettii appear as a slight blemish and often form erumpent scab pustules comprised of fungal hyphae and host tissue. The affected leaves may develop lesions with warty or protuberant pustules emerging from one side of the leaf and a corresponding depressed area on the opposite side (Wang et al. 2009).

\footnotetext{
${ }^{1}$ Universidade Estadual Paulista (Unesp), Departamento de Botânica, IB, 13.506-900, Rio Claro, SP, Brazil. *E-mail: marcelo_claro@yahoo.com.br

${ }^{2}$ Unesp, Departamento de Fitossanidade, FCAV, 14.884-900, Jaboticabal, SP, Brazil

${ }^{3}$ Embrapa Mandioca e Fruticultura Tropical, EECB, CP 74, 14.700-971, Bebedouro, SP, Brazil
} 
MC Souza et al.

Currently fungicides, mainly cuprics, represent the primary means of controlling citrus scab (Feichtenberger et al. 1986, Mondal et al. 2007). Another alternative is to grow more resistant varieties, standing out as being the cheapest and easiest to use (Camargo and Bergamin Filho 1996).

Among the studies performed to select resistant citric varieties, Faling et al. (2004) presented the Kiyomi tangor hybrid from mandarin and orange as resistant to citrus canker and scab. AiJum (2004) presented the 'Cuipijingan' (Fortunella japonica) cultivar as resistant to citrus canker, scab, and tolerant to the Citrus tristeza virus. Yoshida et al. (2003) presented the 'Puchimaru' (Fortunella sp.) cultivar, a cross between 'Naga Kinkan' and 'Ninpou Kinkan' tetraploid, as being resistant to citrus canker and moderately resistant to scab.

Included among the susceptible hosts to E. fawcettii, are different lemon and sour orange species (Laranjeira et al. 2005), pomelo, some mandarin varieties, 'King' tangerine 'Satsuma', 'Cravo', Poncirus trifoliata, calamondin (Citrus mitis) and kaffir lime (Citrus hystrix). The kumquats (Fortunella spp.) and the majority of oranges and limes are generally more resistant, examples of infection in these hosts are known (Jotani 1957).

This study sought to select potential agronomic genotypes of tangerine resistant to E. fawcettii, under natural infection conditions.

\section{MATERIAL AND METHODS}

\section{Selection of the tested materials}

Botanical classification of the varieties and hybrids was performed according to descriptions reported by Ortiz Marcide (1986). All of the elected citrus material (22 genotypes) belonged to the Germplasm Bank at the Estação Experimental de Citricultura de Bebedouro (EECB), located in the Northern region of the State of São Paulo (lat $20^{\circ} 532$ $163 \mathrm{~S}$, long $48^{\circ} 282113 \mathrm{~W}$, and alt $680 \mathrm{~m}$ asl), Brazil, in a $6 \mathrm{~m} \times 3 \mathrm{~m}$ spacing (555 trees per ha), on a total area of $1,944 \mathrm{~m}^{2}$. The climate is Köeppen's Cwa, with a mean temperature of $23.5^{\circ} \mathrm{C}$ and an annual rainfall of $1,522 \mathrm{~mm}$. The soil is classified as Haplustox (38 \% clay) (Embrapa 1999). Given the disease history over the last years, it has become unnecessary to achieve pathogen inoculation in the experimental area. However, to ensure an appropriate inoculum level, fungicides were not sprayed in the critical phases of leaf susceptibility nor two years before the implementation of the experiment in fruits. Other cultural practices were performed according to the adopted methods used in commercial orchards.

One year prior to assessing the performance of the genotypes to E. fawcettii, the degree of potential agronomic value was evaluated. This latter measure was determined by previous evaluation of palatability and phenotypic characteristics such as appearance, coloration and ease of peeling, as well as resistance tests to Alternaria alternata. The genotypes evaluated are on Table 1.

\section{Evaluation of disease severity}

From April to May, 2008, when fruit maturation begins, 100 fruits were collected per genotype in three plants, totaling 300 fruits per genotype located in the middle of the plant as well as distributed across all four quarters.

The evaluation was performed giving scores using the following system: 0 - absence of symptoms, $1-0.5 ; 2$ $-2.5 ; 3-6.0 ; 4-12.5 ; 5-25$; and $6-50 \%$ of the infected area (Feichtenberger et al. 1986). The amount of lesions reported, was assessed, and the average number of lesions was calculated as adapted from Reis et al. (2007) and Souza et al. (2009).

\section{RESULTS AND DISCUSSION}

Among the resistant genotypes, 5 mandarins were found corresponding to one $C$. reticulata, one C. deliciosa, two $C$. tangerina, one $C$. nobilis; one mandarin (hybrid) resulting from crossing $C$. nobilis x $C$. deliciosa and one satsuma (hybrid) resulting from crossing C. unshiu $\mathrm{x}$ C. deliciosa (Table 1). For the other genotypes, the infection level ranged from 1 to 3 . Due to this, they were considered moderately resistant, not exhibiting any highly susceptible cultivar when compared to rangpur lime (susceptibility pattern).

In the present study, several degrees of disease severity were observed, even in fruits of the same species, as in clementines (C. clementina), mandarins (C. reticulata) and moderate from satsumas (hybrids) (C. unshiu $\mathrm{x}$ C. sinensis). However, in the case of species whose fruits were classified as moderately resistant, fruits with no symptoms were not observed, showing a good inoculum distribution among the plants. Variations in severity levels were also observed by other researchers in studies involving this pathosystem Citrus-E. fawcettii (Inque et al. 1985). In a similar study, Reddy et al. (1986), aiming to 
Reaction of tangerines genotypes to Elsinoe fawcettii under natural infection conditions

Table 1. Genotypes sampled as resistant or susceptible to Elsinoe fawcettii, under natural infection conditions

\begin{tabular}{|c|c|c|}
\hline Genotypes & Natural infection of Scab in fruits* & Resistance to Alternaria Brown Spot** \\
\hline \multicolumn{3}{|l|}{ Clementines } \\
\hline \multicolumn{3}{|l|}{ (C. clementina) } \\
\hline Clementina $2 \mathrm{Kr}$ Monreal & 1 & HR \\
\hline Commune SRA- 88 & 0 & HR \\
\hline Caffin SRA-385 & 0 & HR \\
\hline Bruno SRA-531 & 0 & HR \\
\hline \multicolumn{3}{|l|}{ Mandarin } \\
\hline \multicolumn{3}{|l|}{ (C. reticulata) } \\
\hline Burgess SRA 412 & 0 & HR \\
\hline Fewtrell SRA-418 & 2 & HR \\
\hline Daisy Mandarin & 3 & $\mathrm{AR}$ \\
\hline \multicolumn{3}{|l|}{ (C. deliciosa) } \\
\hline Peau Lisse SRA 267 & 0 & HR \\
\hline \multicolumn{3}{|l|}{ (C. tangerina) } \\
\hline Zanzibar SRA 442 & 0 & HR \\
\hline Beauty Of Glen Retreat SRA 261 & 0 & HR \\
\hline \multicolumn{3}{|l|}{ (C. nobilis) } \\
\hline Rode King SRA 431 & 0 & HR \\
\hline \multicolumn{3}{|l|}{ Satsumas } \\
\hline \multicolumn{3}{|l|}{ (C. unshiu) } \\
\hline Satsuma NC (nucellar clone) & 1 & AR \\
\hline \multicolumn{3}{|l|}{ Tangelos } \\
\hline \multicolumn{3}{|l|}{ (C. tangerina $\times$ C. paradisi) } \\
\hline Nocatee SRA-452 (B) & 1 & HR \\
\hline \multicolumn{3}{|l|}{ Mandarin (hybrids) } \\
\hline \multicolumn{3}{|l|}{ (C. nobilis $\mathrm{x} C$. deliciosa) } \\
\hline Encore SRA 190 & 0 & HR \\
\hline \multicolumn{3}{|l|}{ (C. clementina $\mathrm{x} C$. reticulata) } \\
\hline Fremont & 3 & HR \\
\hline \multicolumn{3}{|l|}{ Tangor (hybrids) } \\
\hline \multicolumn{3}{|l|}{ (C. temple $\mathrm{x}$ C. tangerina) } \\
\hline Temple x Dancy Mandarin & 1 & $\mathrm{AR}$ \\
\hline \multicolumn{3}{|l|}{ (C. clementina $\times$ C. sinensis) } \\
\hline tangerina Clementina $\mathrm{x}$ laranja Tarocco & 1 & HR \\
\hline \multicolumn{3}{|l|}{ Satsuma (hybrids) } \\
\hline \multicolumn{3}{|l|}{ [C. unshiu $\mathrm{x}($ C. Reticulata $\mathrm{x}$ C. sinensis $)]$} \\
\hline Satsuma x Murcote (EECB 34) & 1 & $\mathrm{AR}$ \\
\hline Satsuma x Murcote 4 (EECB 3) & 1 & $\mathrm{AR}$ \\
\hline \multicolumn{3}{|l|}{ (C. unshiu $\mathrm{x}$ C. sinensis) } \\
\hline Satsuma x Natal (EECB 30) & 0 & HR \\
\hline Satsuma x Natal (EECB 41) & 1 & $\mathrm{AR}$ \\
\hline Satsuma x Natal 3 (EECB 12) & 1 & HR \\
\hline
\end{tabular}


select resistant Rough lemon to E. fawcettii, also observed reactions varying from immune to highly susceptible. Among the selected immune fruits were 'Shomyndong', 'Milan', 'Khattazamir', 'Brazilian Rough lemon' and 'Chase Rough lemon'.

Researches aiming to select resistant tangerine species to E. fawcettii have been conducted worldwide. In this context, Matsumoto et al. (2003a) observed that 'Nishinokaori' tangor, a crossing of 'Kiyomi' tangor and 'Trovita' orange, was resistant to this pathogen. In the present study, except for Burgess SRA 412 mandarin, all other genotypes belonging to or deriving from crosses of $C$. reticulata showed moderate to low resistance to the fungus.

The resistance verified in Burgess SRA 412 mandarin, obtained from just one cultivar of $C$. reticulata, deserves more detailed researches. Bitancourt (1935) for example, observed that other tangerines of common ancestors, like 'Cravo' mandarin, showed to be susceptible to E. fawcettii and E. australis, differing from the results obtained.

An Encore SRA 190 (C. nobilis x C. deliciosa) mandarin hybrid showed to be resistant to E. fawcettii, like 'Setoka' (C. sinensis $\mathrm{x} C$. reticulata) cultivar, a crossing of Kuchinotsu n 37 (Kiyomi x Encore n ${ }^{\circ} 2$ ) and Murcott tangor, which is resistant to scab and also Xanthomonas axonopodis pv. citri (Hasse) (Matsumoto et al. 2003b). Thus, given the history, it appears that the resistance observed is due to Encore SRA (B) mandarin genes, showing its potential for studies in breeding programs aimed at controlling this pathogen.

Finally, Commune, Caffin, Bruno, Burgess, Peau Lisse, Zanzibar, Beauty of Glen Retreat, Rode King and Encore cultivars, have demonstrated good agronomic characteristics; being resistant to E. fawcettii and, according to Reis et al. (2007) and Souza et al. (2009), also resistant to A. alternata, presenting the viability of a promising economic exploration.

\title{
Reação de genótipos de tangerinas a Elsinoe fawcettii sob condições de infecção natural
}

\begin{abstract}
RESUMO - A verrugose dos citros, causada pelo fungo Elsinoe fawcettii, encontra-se presente em todas as áreas citrícolas do Brasil. Dada sua importância, o comportamento de acessos e híbridos de tangerinas foi avaliado sob condições naturais de infecção. O estudo envolveu plantas não irrigadas, com 15 anos de cultivo, sendo coletados 100 frutos de três plantas por genótipo, na fase de colheita. Mediante o emprego de escala de notas que variaram de 0 (ausência de sintomas) a 6 (sintomas severos), procedeu-se a avaliação do nível de severidade da doença. Dentre genótipos que mostraram-se resistentes incluem-se Citrus deliciosa, C. tangerina, C. nobilis; um híbrido de mandarina (C. nobilis $x$ C. deliciosa) e um híbrido de satsuma (C. unshiu $x$ C. sinensis). Nos demais genótipos foram encontrados sintomas, cujos níveis de severidade variaram de 1 a 3 , enquadrando-os como de moderada resistência.
\end{abstract}

Palavras-chave: verrugose, citricultura, variedades resistentes.

\section{REFERENCES}

AiJun C (2004) The biological characteristics of citrus cultivar Cuipijingan. South China Fruits 33: 11-12.

Bitancourt AA (1935) A história da verrugose. O Biológico 1: 391397.

Camargo LEA and Bergamin Filho A (1996) Controle genético. In Bergamin Filho A, Kimati A and Amorim L (ed) Manual de fitopatologia: princípios e conceitos. $3^{\text {rd }}$ ed., Ceres, São Paulo, p. 729-760.
Embrapa (1999) Centro Nacional de Pesquisa de Solos. Sistema brasileiro de classificação de solos. Embrapa, Rio de Janeiro, $412 \mathrm{p}$.

Faling W, Jianguo X and Puzhi K (2004) The biological characteristics of Kiyomi tangor citrus cultivar and its utilization in citrus breeding. South China Fruits 33: 8-9.

Feichtenberger E, Eskes AB, Prates HS and Sabatini V (1986) Resultados de experimentos recentes sobre o controle de verrugose e melanose dos citros. Laranja 7: 173-208. 
Goes A and Reis RF (2009) Caracterização e controle de doenças das tangerineiras. In Koller OC (ed) Citricultura: cultura de tangerineiras, tecnologia de produção, pós-colheita e industrialização. Rigel, Porto Alegre, p. 251-254.

Hyun JW, Peres NA, Yi S-Y, Timmer LW, Kim KS, Kwon H-M and Lim H-C (2007) Development of PCR assays for the identification of species and pathotypes of Elsinoë causing scab on citrus. Plant Disease 91: $865-870$.

Hyun JW, Yi SH, MacKenzie SJ, Timmer LW, Kim KS, Kang SK, Kwon HM and Lim HC (2009) Pathotypes and genetic relationship of worldwide collections of Elsinoë spp. causing scab diseases of citrus. Phytopathology 99:721-728.

Inque K, Iguchi I, Hara S and Takeda Y (1985) Resistance of citrus nucellar seedlings of citrus crosses to scab (Elsinoe fawcettii Bitanc. E Jenkins). Bulletin of the Shizuoka Prefectural Citrus Experiment Station 21: 27-33.

Jotani Y (1957) On the scab of the 'Kindzu' or 'Golden bean' orange plant. Journal of Japanese Botany 32: 92-95.

Laranjeira FF, Amorim L, Bergamin Filho A, Aguilar-Vildoso CI and Coletta Filho HDC (2005) Fungos, procariotos e doenças abióticas. In Mattos Júnior D, De Negri JD, Pio RM and Pompeu Junior J. (ed) Citros. Instituto Agronômico/FUnDAG, Campinas, p. 223277.

Matsumoto R, Yamamoto M, Kuniga T, Okudai N, Yamada Y, Takahara T, Oiyama I, Ishiuchi D, Murata H, Asada K, Ikemiya H, Shichijo T, Yoshinaga K, Uchihara S and Ieki H (2003a) New citrus cultivar Nishinokaori. Bulletin of the National Institute of Fruit Tree Science 2: 17-23

Matsumoto R, Yamamoto M, Kuniga T, Yoshioka T, Mitani N, Okudai $\mathrm{N}$, Yamada $\mathrm{Y}$, Asada $\mathrm{K}$, Ikemiya $\mathrm{H}$, Yoshinaga K, Uchihara $\mathrm{S}$, Oiyama I and Murata H (2003b) New citrus cultivar Setoka. Bulletin of the National Institute of Fruit Tree Science 2: 25-31.

Mondal SN, Vicent A, Reis RF and Timmer LW (2007) Efficacy of pre-and postinoculation application of fungicides to expanding young citrus leaves for control of melanose, scab, and alternaria brown spot. Plant Disease 91: 1600-1606.
Ortiz Marcide JM (1986) Nomenclatura botánica de los cítricos. Fruits 41: 199-209.

Reddy MRS, Naidu PH and Reddy GS (1986) Screening Rough lemon and Rangpur lime strains for resistance to citrus scab. Current Science 55: 152-153.

Reis RF, Almeida TF, Stuchi ES and Goes A (2007) Susceptibility of citrus species to Alternaria alternata, the causal agent of the Alternaria brown spot. Scientia Horticulturae 113: 336-342.

Rodrigues JCV, Kitajima EW, Childers CC and Chagas CM (2003) Citrus leprosis virus vectored by Brevipalpus phoenicis (Acari: Tenuipalpidae) on citrus in Brazil. Experimental and Applied Acarology 30: 161-179.

Souza MC, Stuchi ES and Goes A (2009) Evaluation of tangerine hybrid resistance to Alternaria alternata. Scientia Horticulturae 123: 1-4.

Tan MK, Timmer LW, Broadbent P, Priest M and Cain P (1996) Differentiation by molecular analysis of Elsinoë spp. causing scab diseases of citrus and its epidemiological implications. Phytopathology 86: 1039-1044.

Timmer LW, Pries M, Broadbent P and Tan MK (1996) Morphological and pathological characterization of species of Elsinoe causing scab disease of citrus. Phytopathology 86: 1032-1038.

Wang LY, Bau H-J, Liao H-L and Chung K-R (2009) Factors affecting the production of elsinochrome phytotoxin by the citrus scab pathogen, Elsinoë fawcettii. The Open Mycology Journal 3: 1-8.

Yoshida T, Nesumi H, Yoshioka T, Ieki H, Ito Y, Nakano M, Ueno I, Yamada Y, Murase S and Takishita F (2003) New kumquat cultivar Puchimaru. Bulletin of the National Institute of Fruit Tree Science 2: 9-16. 